\title{
A Reproductive Health Learning Model For Adolescents At Pesantren In Madura Of East Java, Indonesia
}

\author{
Khoirul Rosyadi \\ Sociology Department, Social and Culture Faculty, Trunojoyo University, Madura, \\ khorosid@yahoo.com
}

\begin{abstract}
The focus of this study was the phenomenon of learning practices about reproductive health maintenance and care among the pesantren communities. The purpose of the present study was to analyze and develop a pesantren-based adolescent reproductive health learning model. The present (method) study was a descriptive analytic study by the use of a cross-sectional design and a qualitative approach. It was conducted in some pesantren in Madura (Bangkalan, Sampang, Pamekasan and Sumenep Regencies). The result research show that there productive health model learning for adolescents at pesantren, potentially implementable in pesantren in Madura region, covers aspects of materials, learning methods and media used.
\end{abstract}

Keywords: Learning model, reproductive health, pesantren

\section{INTRODUCTION}

Problems related to reproductive health include, among others, unsafe sexual behavior; sexually transmitted diseases such as STIs and HIV/AIDS; infectious diseases caused by lack of reproductive organ hygiene; drugs; unwanted pregnancy; abortion; early marriage; having too many children; as well as violence and sexual abuse. Antara News (2012) reported that the number of adolescents in Indonesia was more than 70 million, or 13 times the population of Singapore. In addition, a study conducted by University of Indonesia and the Australian National University in 2010 indicated that as many as $20.9 \%$ of girls in Indonesia has become pregnant as a result of extra-marital sex and $38.7 \%$ have experienced early marriage. Also, of the thousands of cases of HIV/AIDS for the 2005-2012 period, 45\% were contributed by adolescents.

Ministry of Health of Republic of Indonesia (2011) stated that Madura had a very high infant mortality rate compared with the rest of the other regions in East Java. Additionally, according to the results of the spatial analysis conducted by the $\mathrm{MoH}$ of Republic of Indonesia (2011), this region had some conditions highly correlated with the incidence of infant mortality. These conditions included the highest proportion of poor population (28.52 to $39.42 \%)$; the highest number of malnourished and undernourished children under five years old (21 to $31.16 \%$ for the regions of Bangkalan, Pamekasan, Sumenep and Sampang); percentage of the distance to the nearest health facility (less than $1 \mathrm{~km}$ ) in very low category (22.8 to $32.9 \%$ ); low percentage of access to delivery assisted by health personnel (31.69 to $60.92 \%$ ); and the number of traditional birth attendants 1.5 to 3 times that of midwives. Also, the prevalent cultures of early marriage among the Madurese constituted one of the causes of high infant mortality rate.

These facts indicate serious reproductive health problems among adolescents in Madura. Taboos and lack of openness to information related to sexual behavior among the community are among the reasons teenagers looking for indecent information. As a result, sexually deviant 
behaviors, such assame-sex intercourse (Wijaya, 2008) and the dating culture among santri (Ardianingsih, 2005; Rifa'i, 2009). There is an increasing concern that it may cause further negative impacts, ranging from moral decadence, free sex, to the trend of early marriages, as well as extra-marital pregnancy. Therefore, comprehensive reproductive health education by the use of a pesantren-based learning model is needed. Moreover, pesantren represents the Madurese's educational institution of main choice for their children.

The focus of this study was the phenomenon of learning practices about reproductive health maintenance and care among the pesantren communities. The problem statement of this study is how was the practice learning about reproductive health among pesantren communities? And what was the framework of appropriate adolescent reproductive health learning model to improve the reproductive health independence among pesantren adolescents and communities at large?

The purpose of the present study was to analyze and develop a pesantren-based adolescent reproductive health learning model. More specifically, the objectives of this study were to:

1. Identify practices of adolescent reproductive health maintenance at pesantren.

2. Develop a framework of an appropriate adolescent reproductive health learning model to improve the reproductive health independence of adolescents at pesantren.

With the appropriate learning model, it is expected that adolescents at pesantren would received correct and comprehensive information on reproductive health, which in turn makes them who graduated from pesantren better prepared to decide how to maintain and care their reproductive health. It can indirectly minimize the phenomenon of early marriage in Madura region as santriwati would have a better understanding of the impact to be encountered in the future. This learning model is indispensable as a preventive effort either to reduce the issue of unsafe sex or to reduce the number of abortions or, in the long term, to reduce infant mortality rate in Indonesia, especially in Madura.

\section{METHODS}

The present study was a descriptive analytic study by the use of a cross-sectional design and a qualitative approach. It was conducted in pesantren in Madura (Bangkalan, Sampang, Pamekasan and Sumenep Regencies) for one year (2013). Each regency was represented by two (2) types of pesantren: Salafi and modern. Subjects of the study were administrators, ustadz and ustadzah (male and female religious teacher, respectively) and kyai (Muslim cleric). For each type of pesantren, those representative pesantren considered as mastering the learning system concerned, especially those providing the learning related to adolescent reproductive health education in pesantren, were taken. The researcher also took study subjects external to pesantren, i.e., health personnel, when they delivered reproductive health education to the santri. Purposive sampling technique was used for selection of study subjects. Prior to data collection, the researcher explained the purpose and objectives of the research, ask the subject's willingness to participate in the study and asked for proof of willingness to participate by completing an informed consent. It was only then that the researcher collected data. Subsequently, data was collected by conducting in-depth interviews with subjects, as well as directing observing the physical conditions and social phenomenon and the learning process of the subjects during the study. The researcher triangulated the data obtained by conducting interviews with informants, such as santri/santriwati and local health personnel. 


\section{A. Model Reframing Process}

During the process of reframing a reproductive health learning model for pesantren communities, the researcher conducted discussions with pesantren stakeholders regarding the concept and importance of reproductive health independence for adolescents at pesantren through a learning process. Subsequently, the researcher asked participants to the study, especially stakeholders of the pesantren concerned, to discuss a reproductive health learning model most appropriately applied to adolescents at pesantren that could be implemented together in order to achieve the goal of adolescent reproductive health independence. Then, the researcher analyzed the results of these discussions descriptivephenomenologically and developed a framework of pesantren-based adolescent reproductive health learning model.

\section{B. Conceptual Framework of the Study}

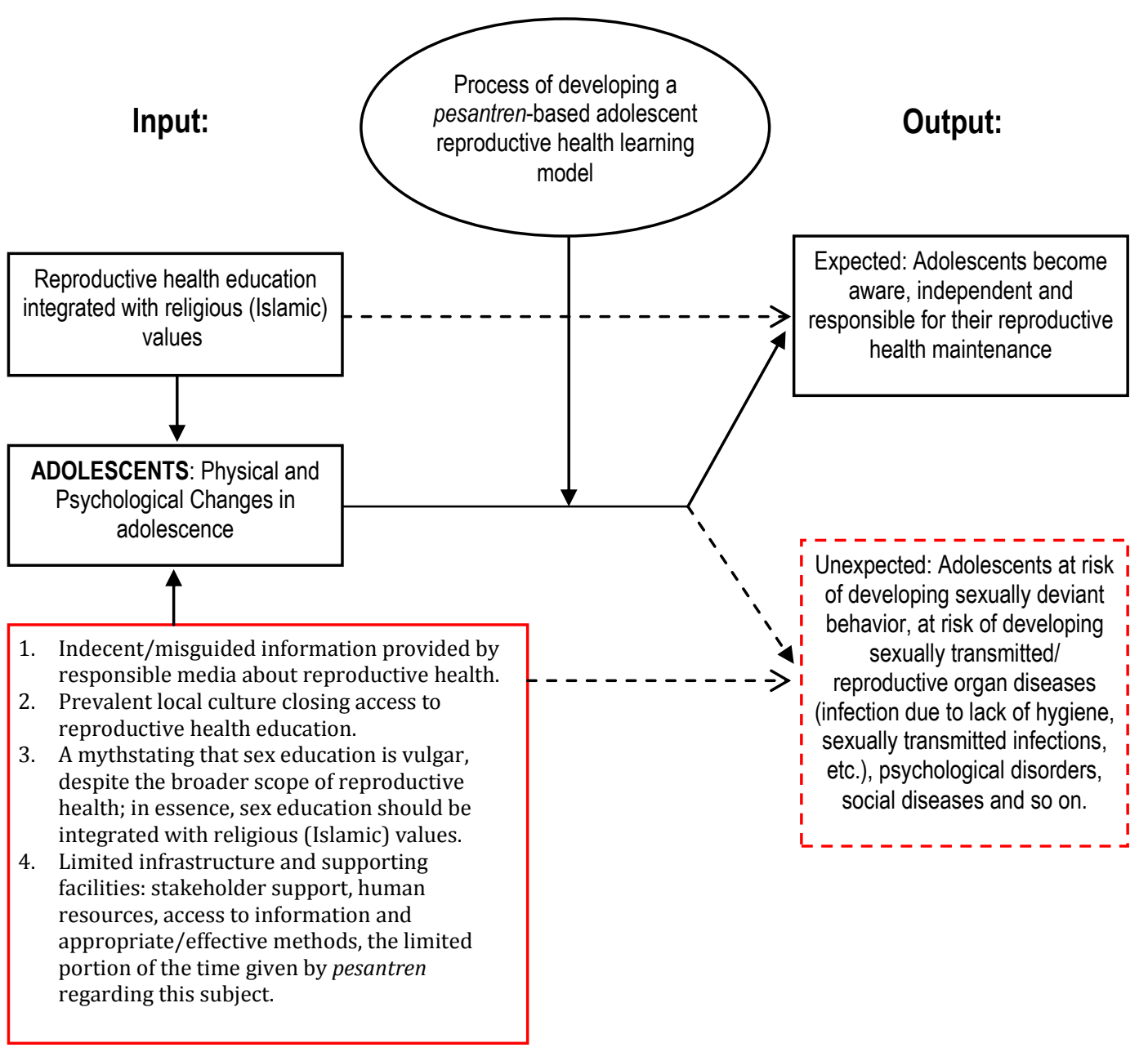




\section{RESULTS AND DISCUSSIONS}

\section{A. Characteristics of Subjects}

\begin{tabular}{|c|c|c|c|}
\hline \multicolumn{4}{|c|}{$\begin{array}{c}\text { Table } 1 \text { Characteristics of Teachers at Pesantren by Age, Education, Teaching } \\
\text { Experience and Major Role at Pesantren in Madura Region }\end{array}$} \\
\hline No. & Characteristics & Total & $\%$ \\
\hline \multirow[t]{5}{*}{1.} & Age & & \\
\hline & 20-30 years & 6 & 75.0 \\
\hline & $31-40$ years & 1 & 12.5 \\
\hline & 41 years and older & 1 & 12.5 \\
\hline & Total & & \\
\hline \multirow[t]{7}{*}{2.} & Education & & \\
\hline & Bachelor's degree (educational and STAIN/State Islamic College) & 2 & 25 \\
\hline & Pesantren & 1 & 12.5 \\
\hline & Madrasah diniyah (Islamic school) & 1 & 12.5 \\
\hline & $\begin{array}{l}\text { Senior High School/Graduate of 'Package C' of Equivalency } \\
\text { Education Program }\end{array}$ & 3 & 37.5 \\
\hline & Junior High School & 1 & 12.5 \\
\hline & Total & 8 & 100 \\
\hline \multirow[t]{7}{*}{3.} & Teaching experience at Pesantren & & \\
\hline & $1-3$ years & 4 & 50 \\
\hline & 4-5 years & 1 & 12.5 \\
\hline & 6-10 years & 0 & 0 \\
\hline & $10-20$ years & 2 & 25 \\
\hline & 20 years or more & 1 & 12.5 \\
\hline & Total & 8 & 100 \\
\hline \multirow[t]{5}{*}{4.} & Major Position/Role in Pesantren & & \\
\hline & Management Board & 6 & 75 \\
\hline & Teacher & 1 & 12.5 \\
\hline & Management Board and Teacher & 1 & 12.5 \\
\hline & Total & 8 & 100 \\
\hline
\end{tabular}

In the present study, $75 \%$ of the informants were the member of management board of the pesantren who were also the teachers for subjects related to reproductive health in pesantren. Most (75\%) were dominated by informants with those aged between 20 to 30 years. Furthermore, most of them (37.5\%) were graduates of senior high school/Package $\mathrm{C}$ and $25 \%$ had a bachelor's degree. In terms of teaching experience, $50 \%$ of the teachers had $1-3$ years of experience and approximately $20 \%$ had 10-20 years of experience. The above description of the representative 
characteristics of teachers at pesantren indicated a current limitation of the available human resources in terms of academic competence since only $25 \%$ of the teachers had a bachelor's degree.

\section{B. Description of Study Location}

The following is an overview of the characteristics of pesantren studied, which are spread over four regencies in Madura: Bangkalan, Sampang, Pamekasan and Sumenep.

Interviews with informants in four regencies of Madura showed that there were marked differences between Salafi and modern pesantren. One characteristic of Salafi pesantren was the intensive study of Salafi books or kitab kuning. Their learning methods were developed by their own teachers or boards of management and nonformal in nature. However, some of them allowed their female students to attend formal education outside pesantren.

The hallmark of the modern pesantren was a system that sought to implement an integrated formal and non-formal education. Formal and non-formal education was developed in parallel and complementarily in order to achieve the goals of pesantren; students were not only provided with subjects of kitab kuningbut the general scienceswere also included in the curriculum of pesantren.

\section{Practices of Reproductive Health Learning at Pesantren in Madura Region}

Almost all Salafi pesantren did not provide subjects on reproductive health in a specific learning, but almost all Salafi pesantren believed that subjects associated with reproductive health have been are included in the subjects of kitab kuning. Here is a detailed description of each of the pesantren with regard to adolescent reproductive health learning at pesantren in 4 (four) regencies in Madura (Matrix 2).

Matrix 2 shows that almost all Salafi pesantren have not or did not provide reproductive health subjects to santri/santriwati, but nearly all of informants from Salafi pesantren stated that studies related to reproductive health subjects have already been contained in Salafi books. Subjects related to adolescent reproductive health included menstruation, puberty, avoidance of immoral behaviors, getting in touch with friends and the opposite sex and marriage. Those subjects already existed in kitab kuning, among others, Fathul Qorib Fath, the commentary Al Kallam, Ayyuhal Walad, the Barjuri Book and the Sarqowi Book and others. Those subjects were also related to akhlaq and fiqh, which were given to santri/santriwati1-2 times a week by their own ustadz/ustadzah. In addition, there was one Salafi pesantren that also used learning resources other than kitab kuning used to help ustadz/ustadzah present the subjects, i.e. books and video tutorials on menstruation for santriwati. Methods of learning used in Salafi pesantren both for general subjects and those related to reproductive health ranged from traditional methods, such as classical, Weton (a method of teaching in which santri sit in a circle in front of kyai working on various texts) and Sorogan, lectures, discussions, self-taught (reading alone in the library), to field practice. According to the informants, the method of learning considered as the most effective was Sorogan.

Most of modern pesantren have already taught subjects of adolescent reproductive health in the form of a special learning delivered either by ustadz/ustadzah or kyai, which was supported by fairly competent speakers such as local health personnel, health office and the police.There was only one pesantren that admitted not providing reproductive health subjects and those related to reproductive health for adolescent santri/santriwati, namely the modern pesantren Al-Ibrohimy of Bangkalan. However, the board of management explained that the general subjects related to akhlaq were still given. The subjects were delivered by ustadz/ustadzah. Methods of 
learning commonly used for teaching and learning at pesantren during this time were lecture and questions and answers. According to the informants, the method considered as the most effective was questions and answers since santri/santriwati were required to be active in receiving the materials. However, another respondent argued that practice was the most effective methods since santri/santriwati could directly apply the materials given.

The other three modern pesantren stated that they already provided subjects on adolescent reproductive health, such as menstruation, puberty, avoidance of immoral behaviors, getting in touch with friends and the opposite sex and marriage. Those subjects were delivered either specifically or through other related subjects such as fiqh, biology and studies of Kallam books and Kitab Kuning. Learning frequency varied ranging from once a year but there were also subjects delivered simultaneously with the schedules of biology and figh. However, with regard to the delivery of reproductive health subjects specifically such as through health training/counseling, there were pesantren that performed it conditionally but some carried it out every semester. The methods used in delivering reproductive health subjects also varied, ranging from lectures, discussions , and practice, to persuasion and problem solving. Interviews with management boards of pesantren indicated that there were some methods of learning considered as the most effective, such as sharing of ideas, since santri/santriwati and ustadz/ustadzah could discuss more openly and recognize what santri/santriwati needed. In fact, an informant from Sampang argued that essentially there was no one method considered as the most effective since all the methods were complementary, for example, persuasion and problem solving. Likewise, media used in delivering the subjects also varied, ranging from books, power point/projector, to videos displaying the impacts of free sex, to teenage short stories.

\section{Development of Reproductive Health Learning Model for Adolescents at Pesantren in Madura}

Based on discussions with stakeholders of pesantren, almost all the pesantren expected the development of a comprehensive and appropriate learning model for santri/santriwati of pesantren.

Here is the framework of learning model developed by the researcher on the basis of the considerations and inputs provided by those executing the learning process of reproductive health for adolescents atpesantren in Madura region (Figure 1).

The purpose of reproductive health learning for adolescent is to modify adolescents' behaviors to be independent in maintaining their reproductive health on the basis of both scientific knowledge and the laws and philosophy of Islam (rooted in the Quran and Hadith). According to behavioral theories, behavioral modifications require gradual changes starting from improvements in cognitive aspects, followed by improvements in affective aspects and changes in the psychomotor/behavioral aspects. Sources of reproductive health learning materials for adolescents at pesantren within the framework of learning model is a combination of scientific and religious science (Islam) materials that includes, among others:

1. Anatomy and physiology/function of reproductive organs from scientific and religious view points

2. Knowing Adolescence: physiological hormones related to adolescent sexual drives and efforts to respond it as exemplified by the Prophet Muhammad

3. Various deviant behaviors in adolescents and their causes

4. Reproductive health-related diseases and the history of Jahiliyyah

5. Being smart and civilized Santri

In delivering such subjects, the teachers use three (3) major phases. In the initial phase, subjects are delivered by using 
lectures, which is a basic method commonly used in all pesantren in Madura region. This method can be supported by various learning media, ranging from the study of books/kitab kuning/modules on reproductive health, lectures with the aid of whiteboard, to the use of modern technology such as PowerPoint/projector. This method is considered as the basis of a fairly effective method for improving the cognitive aspects of santri/santriwati.

In the middle phase, subjects are delivered the typical method of most pesantren in Madura, Sorogan, with the aid of a communication book for adolescent reproductive health study individualized for each adolescent at pesantren. This communication book is aimed at facilitating reproductive health learning between santri/santriwati and teachers (ustadz/ustadzah who deliver reproductive health subjects). In addition, it serves as a medium of sharing the issues of reproductive health problems potentially experienced by santri/santriwati with their ustadz/ustadzah. Simultaneously, at this stage santri/santriwati can consult individually with their ustadz/ustadzah.

In the final stage, methods emphasizing assistance to santri/santriwati are used to ascertain and analyze the situation of reproductive health problems in the surrounding environment as well as finding out their linkages to the causative factors. Thus, santri/santriwati deeply understand the extent of the reproductive health problem so as to make decisions independently in case of problems associated with reproductive health on themselves and the surrounding environment. This phase uses methods ranging from small-to-medium case studies, followed by discussions in small groups of adolescents and discussion forums with teachers and fellow teenagers on a larger scale. In this phase, the teachers tend to serve as facilitators in the discussions. More creatively, teachers can direct santri/santriwati to make a simple role play related to the case under discussion. This phase can be supported by various media, depending on the imagination of santri/santriwati and teachers. It can include the provision "a card of case studies of reproductive health issues", which is used as a reference for individual assignments of case studies in groups, as well as a movie VCD on reproductive health issues. The learning materials could be given in a special learning, but it could be given simultaneously or integrated with other subjects such as general subjects (biology and penjasorkes) and local content/religious subjects (fiqh and aqidah akhlaq). Moreover, learning could be combined with the materials in kitab kuning, which has been the distinctiveness of all pesantren in Madura region. With the learning model, it is expected that adolescents at pesantren would be able to independently make appropriate decisions with regard to their reproductive health, which would impact on their future health.

\section{CONCLUSIONS}

In conclusion, the current practice of learning reproductive health in pesantren in 4 (four) regencies in Madura was still suboptimal. No single method is effective in enhancing the independence of adolescents at pesantren to care about their reproductive health early on. Efforts of developing a reproductive health learning model for adolescents at pesantren becomes very important to be continuously sought by all parties to spearhead the move towards adolescent independence so as to care about and be able to maintain their reproductive health. The developed model framework should be implementable with the help of the necessary aids, such as modules or learning VCD, structured syllabus and lesson plans, and other necessary media such as casestudies cards of reproductive health issues and communication book for students' reproductive health study. 


\section{RECOMMENDATIONS}

More detailed aids need to be developed in order to describe the developed model framework in the form of concrete lesson plans, syllabus-making, and instructional media as previously suggested. In addition, pesantren community as a whole needs to empowered to succeed in the learning process, especially in capacity building of the teachers/technical mentors during the learning process. Thus, there is a need for basic trainings that cover those aspects in the developed model. In addition,

\section{REFERENCES}

BKKBN. (2008). Buku Pedoman Konseling KRR. Semarang: Pustaka Sinar Harapan.

Faidah, Mutimmatul. (2010). Integrasi Pendidikan Seks dalam Kurikulum Pendidikan Agama Islam (Penelitian Pengembangan bagi Siswa SMA di Surabaya). Disertasi, IAIN Sunan Ampel, Surabaya.

Hurlock, B dan Elizabeth. (2004). Psikologi Perkembangan: Suatu Pendekatan Sepanjang Rentang Kehidupan (Edisi 5), Jakata: Erlangga.

Maslahah, Wafiyatu. (2012). Pembelajaran Seksualitas dan Kesehatan Reproduksi Pada Pesantren Lewat Kajian Kitab Kuning dan Poskestren di Pondok Pesantren Assalam Jambewangi

Selopuro Blitar. Skripsi, Universitas Muhammadiyah. Website: http://karyailmiah.um.ac.id/index.php/sejarah/art icle/view/21484, diakses, 10 Pebruari 2013.

PKBI. (2007). Kehamilan Tidak Direncanakan Pada Remaja. Yogyakarta. Di akses dari http://www.id.wordpress.com/tag/ke sehatan-reproduksi, tanggal 12 Januari 2007. there is a need for developing a network with all relevant sectors, such as health institutions (community health centers and health offices), social services or the police if possible.

\section{ACKNOWLEDGEMENT}

Researchers would like to thank:

- All the informants in this study

- SBRC of Trunojoyo University, BangkalanMadura

- Directorate General of Higher Education, Ministry of National Education,Indonesia

PKBI. (2008). Ragam Perilaku Pacaran Remaja. Jawa Tengah. Di akses dari http://www.suaramerdeka.com/haria n/0503/14/opi04.htm, tanggal 20 Desember 2008.

Rejeki, Sri. (2013). Kesehatan Reproduksi Remaja. Dinas Ksehatan Provinsi DKI Jakarta. Website:http://web.dinkesdki.go.id/dinkesdki/index.php?option $=$ com_content $\&$ view $=$ article $\& i d=77: \mathrm{ke}$ sehatan-reproduksiremaja\&catid $=61$ :kesehatankeluarga\&Itemid $=150$, di akses tanggal 24 Pebruari 2013

Rifa'i, Fauzan. (2009). Kenakalan Remaja di Kalangan Santri Putra di Asrama Diponegoro Asrama Pondok Pesantren Yayasan Ali Maksum Krapyak YogYakarta. Fakultas Tarbiyah UIN Sunan Kalijaga Yogyakarta. Skripsi. Digital Library UIN, Website: http://digilib.uinsuka.ac.id/2689/1/BAB\%201\%2CV.p df, tanggal 22 Pebruari 2013.

Sulistiawati, Endang. (2010). Peran Immaratus Syu'unith Tholabah dalam Mendisiplinkan Santriwati di Pondok Pesantren Al-Mukmin Ngruki Tahun Pelajaran 2010/2011. Skripsi, Universitas Muhammadiyah Surakarta. Website: http://etd.eprints.ums.ac.id/14667/, tanggal 22 Pebruari 2013 
Sugiyanto, Suharyo. (2011). Analisis Praktik Kesehatan Reproduksi Remaja Oleh Guru Bimbingan dan Konseling pada SMP yang Berbasis Agama di Kota Semarang. Jurnal Dian, Vol 11, No 1 tahun 2011. Universitas Dian Nuswantoro Semarang. Website: http://publikasi.dinus.ac.id/index.php /dian/article/view/239/20

Taufiq, dkk. (1998). Peranan Kyai dalam Pemasyarakatan Perilaku Reproduksi Sehat di Kalangan Para Santri (Studi Kasus Pada Pondok Pesautren AIQur'an Buaran Pekalongan). Dokumentasi. Universitas Diponegoro. Website: http://eprints.undip.ac.id/23542八, diakses tanggal 20 Pebruari 2013.

Wahid, Abdurrahman. (2001). Menggerakkan Tradisi. Esai-Esai Pesantren. LKiS, Yogyakarta.

Wijayanti, Retno. (2008). Analisis Sosial Budaya Terhadap Pendidikan Kesehatan Reproduksi Bagi Remaja Pesantren (Studi Kasus di Pondok Pesantren Hidayatul Mubtadi'ien Asrama Putri Sunan Pandanaran di Tulungagung). Website: http://karyailmiah.um.ac.id/index.php/sejarah/art icle/view/809
Jumlah remaja Indonesia 13 kali

penduduk

Singapura,

AntaraNews.com, Senin, 22 Oktober 2012 13:26 WIB, dalam acara sosialisasi mengenai program generasi berencana (Genre) di hadapan ratusan mahasiswa dan pelajar di Universitas Negeri

Gorontalo.http://www.antaranews.co m/berita/339892/jumlah-remajaindonesia-13-kali-penduduksingapura, diakses tanggal 20 Pebruari 2013

Angka remaja putri melahirkan di Indonesia tinggi. AntaraNews.com, Kamis, 14 Februari 2013 21:24 WIB, dalam acara Rakerda Pembangunan Kependudukan dan KB Provinsi Riau tahun 2013, di Pekanbaru. http://www.antaranews.com/berita/3 58471/angka-remaja-putrimelahirkan-di-indonesia-tinggi, diakses tanggal 20 Pebruari 2013 Angka Tertinggi Aborsi Ternyata Usia Remaja. Kompasiana, 12 June 2011,http://muda.kompasiana.com/2 011/06/12/angka-tertinggi-aborsiternyata-usia-remaja-370567.html, diakses tanggal 23 Pebruari 2013 


\section{Matrix 1. Characteristics of Pesantren Studied}

\begin{tabular}{|c|c|c|c|c|c|c|}
\hline No. & Regency & $\begin{array}{l}\text { Type of } \\
\text { Pesantren }\end{array}$ & $\begin{array}{l}\text { Name of } \\
\text { Pesantren }\end{array}$ & Foundation & $\begin{array}{l}\text { Year } \\
\text { Established }\end{array}$ & Characteristic of the Learning in general \\
\hline 1. & Bangkalan & Salafi & $\begin{array}{l}\text { Al-Falah As- } \\
\text { Salafi Al-Cholili } \\
\text { Kepang }\end{array}$ & $\begin{array}{l}\text { Yayasan Al-Falah } \\
\text { As-Salafi }\end{array}$ & 1919 & $\begin{array}{l}\text { Well-dressed;Ahlussunnah Waljamaah; } \\
\text { school time: morning, noon, afternoon, evening }\end{array}$ \\
\hline 2. & Bangkalan & Modern & $\begin{array}{l}\text { Al-Ibrohimy } \\
\text { Galis }\end{array}$ & $\begin{array}{l}\text { YPI Pontren Al- } \\
\text { Ibrohimy }\end{array}$ & 1984 & $\begin{array}{c}\text { Tadarus, tahlil, Shalawat (segue) and deepening of } \\
\text { kitab kuning; education levels provided: Kindergarten, } \\
\text { Madrasah Ibtidaiyah, Madrasah Tsanawiyah, } \\
\text { Madrasah Aliyah and STITAL (college), } \\
\text { madrasahdiniyah and salafiyeh. }\end{array}$ \\
\hline 3. & Sampang & Salafi & $\begin{array}{l}\text { Assirojiyyah } \\
\text { Kajuk }\end{array}$ & $\begin{array}{c}\text { Yayasan } \\
\text { Assirojiyyah Kajuk }\end{array}$ & 1959 & $\begin{array}{l}\text { Intensive study of kitabkuning; school time: morning, } \\
\text { noon, afternoon, evening }\end{array}$ \\
\hline 4. & Sampang & Modern & Darussyahid & $\begin{array}{l}\text { YPI Pontren } \\
\text { modern } \\
\text { Darussyahid }\end{array}$ & 1990 & $\begin{array}{c}\text { Mastery of two languages: Arabic and English; } \\
\text { Rabithah al-Ma'ahid al-Islamiyyah (RMI), junior and } \\
\text { senior high school }\end{array}$ \\
\hline 5. & Pamekasan & Salafi & $\begin{array}{l}\text { Darul Jihad } \\
\text { Cendana }\end{array}$ & $\begin{array}{l}\text { Yayasan } \\
\text { Assyuhada } \\
\text { Cendana }\end{array}$ & 1949 & $\begin{array}{l}\text { Intensive study of kitab kuning; school time: morning, } \\
\text { noon, afternoon, evening }\end{array}$ \\
\hline 6. & Pamekasan & Modern & An-Nasyiin & $\begin{array}{l}\text { Yayasan An- } \\
\text { Nasyiin }\end{array}$ & 1940 & $\begin{array}{l}\text { Mutual respect and mutual cooperation; school time: } \\
\text { morning, noon, afternoon, evening }\end{array}$ \\
\hline 7. & Sumenep & Salafi & $\begin{array}{l}\text { Al Muqri } \\
\text { Assalafi }\end{array}$ & $\begin{array}{l}\text { Yayasan Al Muqri } \\
\text { Aasalafi }\end{array}$ & 1977 & $\begin{array}{l}\text { Intensive study of kitab kuning; school time: morning, } \\
\text { noon, afternoon, evening }\end{array}$ \\
\hline 8. & Sumenep & Modern & Annuqoyah & $\begin{array}{l}\text { Yayasan Ponpes } \\
\text { Annuqoyah }\end{array}$ & 1887 & $\begin{array}{c}\text { kitabiyah, madrassas diniah and Ahlussunnah } \\
\text { Waljamaah; school time: morning, noon, afternoon, } \\
\text { evening }\end{array}$ \\
\hline
\end{tabular}


Matrix 2. Practices of Reproductive Health Learning at Pesantren in Madura Regional

\begin{tabular}{|c|c|c|c|c|c|c|c|}
\hline No. & $\begin{array}{c}\text { Name of } \\
\text { Pesantren } \\
\end{array}$ & $\begin{array}{c}\text { Provision of Reproductive Health } \\
\text { subjects to Santri }\end{array}$ & $\begin{array}{c}\text { Type of } \\
\text { Pesantren }\end{array}$ & Book of Reference & Frequency & Teacher & Methods used \\
\hline 1. & $\begin{array}{l}\text { Al-Falah As- } \\
\text { Salafi Al-Cholili } \\
\text { Kepang }\end{array}$ & $\begin{array}{l}\text { Not providing reproductive health } \\
\text { subjects to santri/ santriwati, but } \\
\text { studies relating to those subjects had } \\
\text { already contained in Salafi books. } \\
\text { Those subjects, among others, were: } \\
\text { menstruation, puberty, avoidance of } \\
\text { immoral behaviors, getting in touch } \\
\text { with friends and the opposite sex } \\
\text { and marriage }\end{array}$ & Salafi & $\begin{array}{l}\text { Kitab kuning: Fathul } \\
\text { Qorib Book, the } \\
\text { commentary Al } \\
\text { Kallam, Ayyuhal } \\
\text { Walad and others }\end{array}$ & $\begin{array}{l}\text { Subjects associated } \\
\text { with akhlaq } \\
\text { (morality) were } \\
\text { provided once in a } \\
\text { week }\end{array}$ & Ustadz / uztadsah & Lecture and field practice \\
\hline 2. & $\begin{array}{l}\text { Al-Ibrohimy } \\
\text { Galis }\end{array}$ & $\begin{array}{l}\text { Have never given subjects on } \\
\text { reproductive health and subjects } \\
\text { associated with it at all, only subjects } \\
\text { on akhlaq (morality). }\end{array}$ & Modern & - & - & - & - \\
\hline 3. & $\begin{array}{l}\text { Assirojiyyah } \\
\text { Kajuk }\end{array}$ & $\begin{array}{l}\text { There was no reproductive health } \\
\text { learning, there were subjects related } \\
\text { to reproductive health, through the } \\
\text { study of fiqh, including menstruation, } \\
\text { puberty, avoidance of immoral } \\
\text { behaviors, getting in touch with } \\
\text { friends and the opposite sex and } \\
\text { marriage }\end{array}$ & Salafi & $\begin{array}{l}\text { Kitab kuning and } \\
\text { other books in the } \\
\text { library }\end{array}$ & $\begin{array}{l}\text { Through fiqh } \\
\text { lessons given twice } \\
\text { a week and two } \\
\text { additional } \\
\text { instruction times } \\
\text { (extra-curricular). }\end{array}$ & Ustadz, Kyai & $\begin{array}{l}\text { Traditional system (salafiyeh) } \\
\text { directed at the implementation of } \\
\text { the three systems, first, classical, } \\
\text { secondWeton, and thirdsorogan, } \\
\text { and through encouraging students } \\
\text { to learn independently through } \\
\text { their own reading of the other } \\
\text { books in the library }\end{array}$ \\
\hline 4. & Darussyahid & $\begin{array}{l}\text { Subjects on adolescent reproductive } \\
\text { health and those related to } \\
\text { reproductive health had already } \\
\text { been given to santri/ santriwati, } \\
\text { even in the Islamic perspective. } \\
\text { Those subjects were related to } \\
\text { adolescent reproductive health, such } \\
\text { as menstruation, puberty, avoidance } \\
\text { of immoral behaviors, getting in } \\
\text { touch with friends and the opposite } \\
\text { sex and marriage. }\end{array}$ & Modern & $\begin{array}{l}\text { Fiqh and Kallam } \\
\text { book. Another } \\
\text { source used by } \\
\text { ustadz/ ustadzah in } \\
\text { providing the } \\
\text { subjects was videos } \\
\text { about the bad } \\
\text { implications of } \\
\text { promiscuity etc. }\end{array}$ & $\begin{array}{l}\text { Subjects were } \\
\text { provided in the form } \\
\text { of training and held } \\
\text { each semester /once } \\
\text { in } 6 \text { months. }\end{array}$ & $\begin{array}{l}\text { Teachers and } \\
\text { health personnel } \\
\text { from the local } \\
\text { health office. }\end{array}$ & $\begin{array}{l}\text { Persuasion and problem solving. } \\
\text { Both were most effective methods } \\
\text { since they were complementary. }\end{array}$ \\
\hline
\end{tabular}




\begin{tabular}{|c|c|c|c|c|c|c|c|}
\hline 5. & $\begin{array}{l}\text { Darul Jihad } \\
\text { Cendana }\end{array}$ & $\begin{array}{l}\text { Not providing reproductive health } \\
\text { subjects in particular learning. Those } \\
\text { subjects related to adolescent } \\
\text { reproductive health, such as } \\
\text { menstruation, puberty, avoidance of } \\
\text { immoral behaviors, getting in touch } \\
\text { with friends and the opposite sex } \\
\text { and marriage had been included in } \\
\text { the curriculum (the Book) of } \\
\text { pesantren. }\end{array}$ & Salafi & $\begin{array}{l}\text { Fathul Qorib Book, } \\
\text { Barjuri Book and } \\
\text { Sarqowi Book. } \\
\text { Learning resources } \\
\text { in addition to the } \\
\text { books used to help } \\
\text { Ustadz/ ustadzah in } \\
\text { presenting the } \\
\text { subjects were books } \\
\text { and video tutorials } \\
\text { on menstruation for } \\
\text { santriwati. }\end{array}$ & $\begin{array}{l}\text { This subject was } \\
\text { given once a week. }\end{array}$ & Ustadz/ ustadzah & $\begin{array}{l}\text { Lecture (mastery of the subjects } \\
\text { and its applications), audio-visual. } \\
\text { Aids in presenting the subjects } \\
\text { already existed ranging from print } \\
\text { media (books, kitab kuning, etc.) to } \\
\text { the electronic media (videos, } \\
\text { pictures, power point). }\end{array}$ \\
\hline 6. & An-Nasyiin & $\begin{array}{l}\text { Already provided subjects on } \\
\text { adolescent reproductive health, } \\
\text { among others: menstruation, } \\
\text { puberty, avoidance of immoral } \\
\text { behaviors, getting in touch with } \\
\text { friends and the opposite sex and } \\
\text { marriage, all taught. }\end{array}$ & Modern & $\begin{array}{l}\text { Kitab kuning, books, } \\
\text { adolescent short } \\
\text { stories and } \\
\text { projector. }\end{array}$ & $\begin{array}{l}\text { Subjects were given } \\
\text { once a year }\end{array}$ & $\begin{array}{l}\text { Ustadz/ uztadzah } \\
\text { as well as health } \\
\text { personnel of the } \\
\text { local puskesmas } \\
\text { (community } \\
\text { health center), } \\
\text { local health office } \\
\text { and the police. } \\
\end{array}$ & $\begin{array}{l}\text { Lecture and sharing of ideas. Aids } \\
\text { in delivering the subjects already } \\
\text { existed ranging from print media } \\
\text { (books) to electronic media } \\
\text { (projectors). }\end{array}$ \\
\hline 7. & $\begin{array}{l}\text { Al Muqri } \\
\text { Assalafi }\end{array}$ & $\begin{array}{l}\text { Not providing subjects on } \\
\text { reproductive health but studies } \\
\text { related to the subjects already } \\
\text { contained in Salafi books. } \\
\end{array}$ & Salafi & $\begin{array}{l}\text { Fathul Qorib Book, } \\
\text { the commentary Al } \\
\text { Kallam, Ayyuhal } \\
\text { Walad and others }\end{array}$ & $\begin{array}{l}\text { Akhlaq (morality) } \\
\text { issues were given } \\
\text { once a week }\end{array}$ & Ustadz/ Ustadzah & $\begin{array}{l}\text { Lecture, discussion and } \\
\text { socialization }\end{array}$ \\
\hline 8. & An-Nuqoyah & $\begin{array}{l}\text { Already provided subjects on } \\
\text { reproductive health to santri. } \\
\text { However, in this case, it was only in } \\
\text { formal school (biology class); in } \\
\text { addition, other issues, in particular } \\
\text { those correlated with the nature of } \\
\text { womanhood such as menstruation, } \\
\text { puberty, avoidance of immoral } \\
\text { behaviors, getting in touch with } \\
\text { friends and the opposite sex and } \\
\text { marriage, were also taught. }\end{array}$ & Modern & $\begin{array}{l}\text { The subjects were } \\
\text { contained in biology } \\
\text { and fiqh books }\end{array}$ & $\begin{array}{l}\text { Health training/ } \\
\text { counseling } \\
\text { performed } \\
\text { conditionally. }\end{array}$ & $\begin{array}{l}\text { Ustadz / } \\
\text { ustadzah), sub- } \\
\text { district and } \\
\text { district health } \\
\text { offices }\end{array}$ & Lecture and practice \\
\hline
\end{tabular}




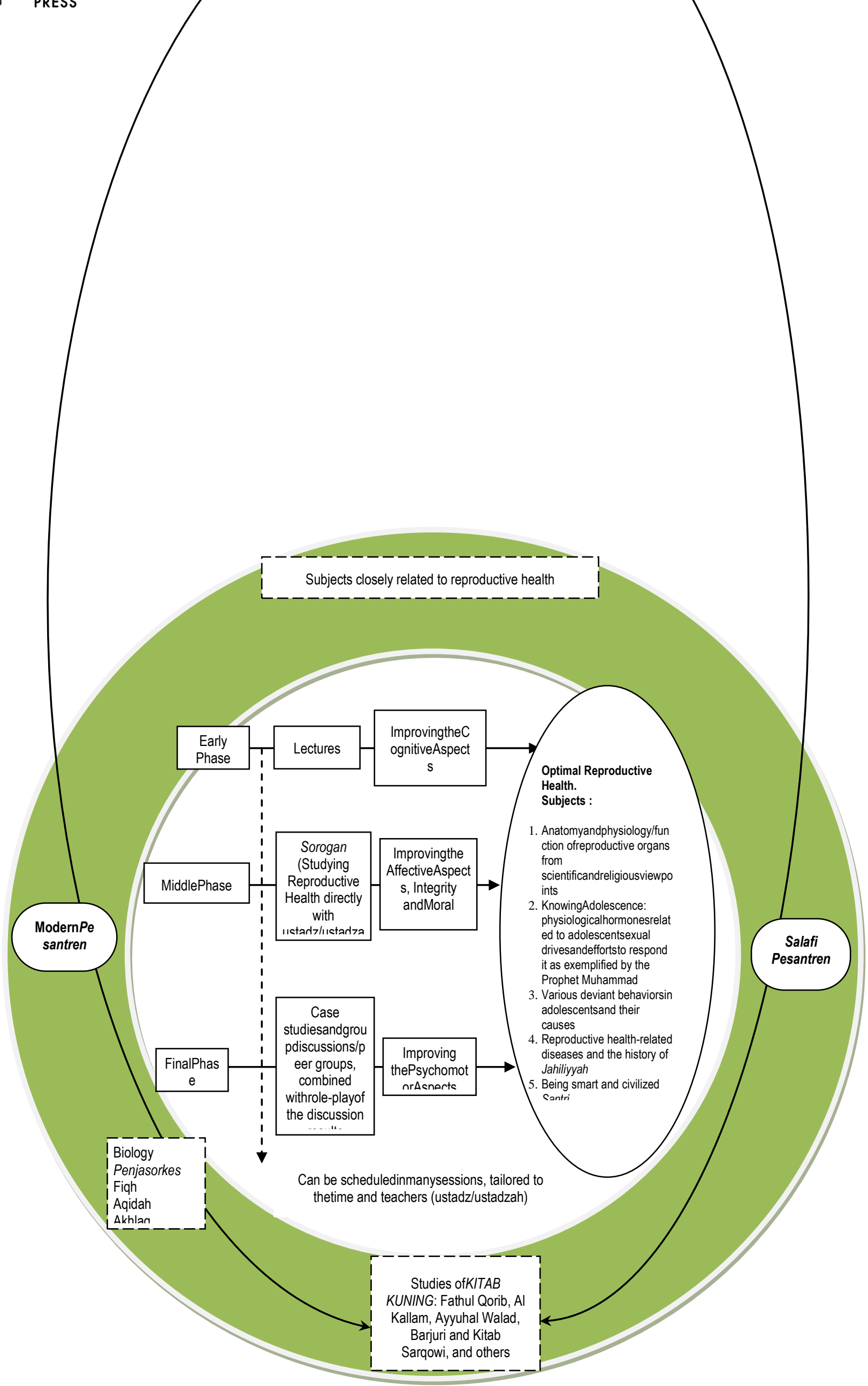

Figure 1

Framework of a reproductive health learning model for adolescents at pesantren in Madura region 